\title{
DISRUPTION AND RECOVERY OF BACTERIAL COMMUNITY STRUCTURE OF AN ATLANTIC FOREST SOIL AFTER EXPOSURE TO GASOHOL
}

\author{
Janaína Fernandes Araújo ${ }^{1}$, Rita de Cássia Rocha Fernandes ${ }^{1}$, Edmo Montes Rodrigues ${ }^{1}$ \& \\ Marcos Rogério Tótola ${ }^{*}$

\begin{abstract}
${ }^{1}$ Universidade Federal de Viçosa, Departmento de Microbiologia, Programa de Pós-Graduação em Microbiologia Agrícola, Laboratório de Biotecnologia e Biodiversidade para o Meio Ambiente, Av. P.H. Rolfs, s/n, Campus Universitário, CEP 36570-900, Viçosa, MG, Brazil.
\end{abstract}

E-mails: janaina.araujo@ufv.br; cassiaalbano1@yahoo.com.br; edmomontes@yahoo.com.br; totola@ufv.br ( ${ }^{*}$ corresponding author)

\begin{abstract}
This article reports the effects of gasohol on the genetic of a bacterial community of a tropical Atlantic Forest soil. Hydrocarbon and ethanol biodegradation was accompanied by $\mathrm{CO}_{2}$ emission. Gasohol had an immediate impact on genetic structure of bacteria and on respiratory metabolism of soil microbial community. Cluster analysis of DGGE band pattern indicated a shift in the community structure between the fifth and fortieth days after contamination. At 60 days after contamination, the DGGE profile of the bacterial community in the contaminated soil was similar to that found in the non-contaminated control. Gasohol addition increased the respiratory rate of the soil, peaking at 3 days and returning to basal level at 15 days after contamination. We concluded that gasohol contamination causes a strong transient impact on soil microbial community structure that is completely reversed after a few days following contaminant removal. Secondary succession after contamination resulted in a bacterial community of identical genetic structure to that found before contamination. Our results point out to a high resilience of microbial community established in Atlantic Forest soil.
\end{abstract}

Keywords: hydrocarbon bioremediation; microbial ecology; microbial succession; resilience; Tropical forest soil.

\section{INTRODUCTION}

Gasohol is a volatile petroleum-derived liquid that is used primarily as a fuel in internal combustion engines. It is obtained by fractional distillation of petroleum, enhanced with a variety of additives, and is considered one of the most important automotive fuels (Demirbas 2009). A collateral effect of the high consumption of gasohol is the contamination of soils and water sources, including aquifers, due to leakages from underground storage tanks and accidental spillages (Corseuil \& Marins 1997, Andrade et al. 2017).
The Atlantic Forest supports one of the highest plant and animal species richness and rates of endemism on the planet (Ribeiro et al. 2009), and is one of the 25 biodiversity hot spots of the world (Faoro et al. 2010). The same must be truth in respect to soil microbial diversity, although few studies have so far addressed the structure of soil microbial communities in this biome. Human activities can change the microbial diversity of soils and, therefore, it is important to evaluate the resilience of the microbial community of soils, mainly in areas with high importance for biodiversity conservation. 
Soil contamination by petroleum hydrocarbons results in reduction of local microbial diversity, which leads to a decrease in microbial biomass, and genetic and functional diversity (Wardle \& Giller 1996, Mummey et al. 2002, Khan et al. 2018), therefore, leading to loss of crucial ecological functions (Jung et al. 2016). The microorganisms play a key role in the biogeochemical cycles, and in this way they actively participate in the transfer of energy and nutrients in the soil (Baldrian 2017). The microbial activity affects directly both soil quality and the productivity of terrestrial ecosystems (Hill et al. 2000, Tótola \& Chaer 2002, Birkhofer et al. 2008). Due to the importance of microorganisms for ecosystem functioning, it is essential to understand how these components of terrestrial ecosystems respond to natural variations and disturbances caused by human activities, including soil contamination by xenobiotics.

Fuel production, transport, and storage may lead to contamination of large areas, due to the massive volumes of these key energy sources consumed in modern human activities (Khan et al. 2018). Soil contamination by hydrocarbons leads to reduction of enzymatic activities (Alrumman et $a l$.2015) and changes of the structure of bacterial and fungal communities (Siles \& Margesin 2018). Once a contamination occurs, remediation of the affected area must be immediately implemented to avoid environmental and economic effects of the contaminants. Remediation of environments contaminated with hydrocarbons can rely on physical, chemical, or biological methods. Physical and chemical treatments usually cause the dispersion of hydrocarbons and do not effective remove them from the environment; moreover, they have high costs. Compared with these methods, biological treatment using microorganisms is costeffective, presents high efficiency and prevents secondary pollution (Khan et al. 2004, Bao et al. 2012). Bioremediation is an effective method for removal of contaminants, and the autochthonous microbial community can usually catabolize the contaminants (Martínez-Pascual et al. 2015).

Several microbial species of bacteria, archaea, and fungi can degrade hydrocarbons present in gasohol (Leahy \& Colwell 1990, Habe \& Omori 2003, El Fantroussi \& Agathos 2005, Rodrigues et al. 2015). In situ microbial bioremediation processes can be classified as natural attenuation, bioaugmentation, or biostimulation (Yu et al. 2005). As reported by Alvarez et al. (2011), natural attenuation relying on the microbial soil community of an Atlantic Forest soil from Rio de Janeiro State was the most cost-effective approach for bioremediation of soil upon hydrocarbons contamination. However, no information about the impact of hydrocarbon contamination on the structure of microbial communities of Atlantic Forest soils was found in the literature.

This study was carried out to evaluate the response of a soil microbial community from the Atlantic Forest to gasohol contamination, in terms of genetic structure.

\section{MATERIAL AND METHODS}

\section{Soil sampling and contamination}

The soil used in this work was collected from the upper $5-15 \mathrm{~cm}$ layer of the Mata da Biologia, located in the campus of the Universidade Federal de Viçosa, which is part of the Atlantic Forest biome, Brazil (2045’31.5”' S 42 $52^{\circ}$ '04.8” W). Twenty samples of soil were collected to result in a composite sample of $2 \mathrm{dm}^{3}$. All experiments were conducted with three replicates.

The soil was air-dried at room temperature, sieved at $2 \mathrm{~mm}$ and thoroughly mixed before chemical and granulometric analyses. The soil received application of nutrients $\left(200 \mathrm{mg} / \mathrm{dm}^{3} \mathrm{P}\right.$, $300 \mathrm{mg} / \mathrm{dm}^{3} \mathrm{~N}-\mathrm{NH}_{4}$ and $100 \mathrm{mg} / \mathrm{dm}^{3} \mathrm{~K}$ ) to stimulate microbial biodegradation of hydrocarbons. The $\mathrm{pH}$ was adjusted between 6.5 and 7.0 with $\mathrm{CaCO}_{3}$ and $\mathrm{MgCO}_{3}$ at the proportion of 5:1 (w/w). Soil samples (20 g) were transferred to plastic pots and humidity was adjusted to $60 \%$ of the water holding capacity. The pots were maintained at $25^{\circ} \mathrm{C}$ throughout the incubation period. One week after fertilization, gasohol (containing $25 \%$ ethanol) was added to the contaminated treatment $(20 \mathrm{~mL} / \mathrm{kg})$. Experimental control consisted of non-contaminated soil.

The experiment was conducted for two months. Samples (5 g) were taken at 0, 5, 10, 15, 25, 40, and 60 days after contamination and used to evaluate genetic diversity of bacteria.

\section{Soil respiration}

A separate experiment was set to study the metabolic response of the soil microbial community to gasohol contamination. The experiment consisted 
of fertilized (refers to 1.1 for dosage) soil samples (10 g dry weight) in $100 \mathrm{~mL}$ Gibco glass flasks. Soil moisture was kept at $60 \%$ water holding capacity. The flasks were kept in a water bath $\left(22^{\circ} \mathrm{C}\right)$ and connected to a respirometer (Sable Systems International, Las Vegas, NE). A CA-2A infrared $\mathrm{CO}_{2}$ detector was used to measure $\mathrm{CO}_{2}$ emission by the soil samples at 5 minutes intervals. Respiration was measured during 60 days, with three replicates for each treatment (non-contaminated control and gasohol-contaminated, $20 \mathrm{~mL} / \mathrm{kg}$ ).

\section{DNA extraction and PCR-DGGE Fingerprint}

Total DNA was extracted from $2 \mathrm{~g}$ soil samples at $0,5,15,25,40$, and 60 days after the onset of the experiment (van Elsas et al. 1997) and then purified using the Wizard Plus SV Minipreps DNA Purification System (Promega). Integrity of DNA samples was checked by agarose gel electrophoresis. On day zero, DNA extraction occurred $2 \mathrm{~h}$ after soil contamination.

Bacterial 16S rRNA genes were amplified by PCR using the oligonucleotides described by Muyzer $e t$ al. (1993) in a Mastercycler Gradient thermocycler (Eppendorf). The reaction mixture $(25 \mu \mathrm{L})$ consisted of $50 \mathrm{ng}$ total DNA, Taq $1 \mathrm{X}$ buffer, 2.4 $\mathrm{mM} \mathrm{MgCl}, 0.2 \mathrm{mM}$ dNTP, $10 \mathrm{pmol}$ of each initiator oligonucleotides, $10 \mu \mathrm{g}$ BSA, $0.5 \mu \mathrm{L}$ formamide and $1 \mathrm{U}$ Taq DNA polymerase (Promega). The amplification cycles were those described by Peixoto et al. (2002). An aliquot of the amplification reaction $(5 \mu \mathrm{L})$ was used to check PCR products by agarose gel electrophoresis. The remainder PCR amplicons were applied onto an $8 \%$ (wt/vol) polyacrylamide gel containing a linear gradient of $45-70 \%$ denaturant (where $100 \%$ denaturant solution contains $7 \mathrm{M}$ urea and $40 \%$ ( $\mathrm{vol} / \mathrm{vol}$ ) formamide). Electrophoresis was performed in $1 \mathrm{X}$ TAE buffer at $60^{\circ} \mathrm{C}$, at a constant voltage of $100 \mathrm{~V}$ for $16 \mathrm{~h}$. After electrophoresis, the gel was stained for 10 min with SYBR Green I (Sigma). The PCRDGGE banding profiles were analyzed with Gel Pro Analyzer R 3.1 software (Media Cybernetics Inc., Maryland-USA). Cluster analysis was performed with Pearson correlation coefficient for the total lane pattern after background subtraction with the BioNumerics software v. 5.10 (Applied Maths, St. Martens Latem, Belgium) and using the unweighted pair group method with arithmetic mean (UPGMA) method (Duineveld et al. 2001).

\section{RESULTS}

\section{Soil respiration}

The addition of gasohol caused a rapid increase of the respiration rate in soil (Figure 1). The respiration rate peaked at the third day, decreasing steadily until reaching the basal level of the non-contaminated control at day 15, indicating complete removal of the newly added substrates (gasohol components).

\section{Effect of gasohol on soil DNA}

The amount of total DNA recovered from the contaminated soil was significantly lower than from the non-contaminated soil $(<50 \mathrm{ng}$ and $>2 \mathrm{mg}$ per sample, respectively; Figure 2). This difference was attributed to a strong toxic effect of gasohol on the microbial soil community components. Fortydays after gasohol addition, the amount of DNA recovered from the contaminated soil was similar to that recovered from the non-contaminated control, indicating the recovery of the soil microbial biomass.

\section{Microbial community fingerprints}

The analysis of the bacterial community profile by DGGE revealed a similar genetic profile in all control samples during the 60-day incubation period (Figure 3A). The genetic profile of the contaminated and control soils shared many common DGGE bands (bands at same position), but with different intensity. A clear separation in two main clusters was detected upon a UPGMA analysis of DGGE profiles (Figure 3B). The contaminated soil at the

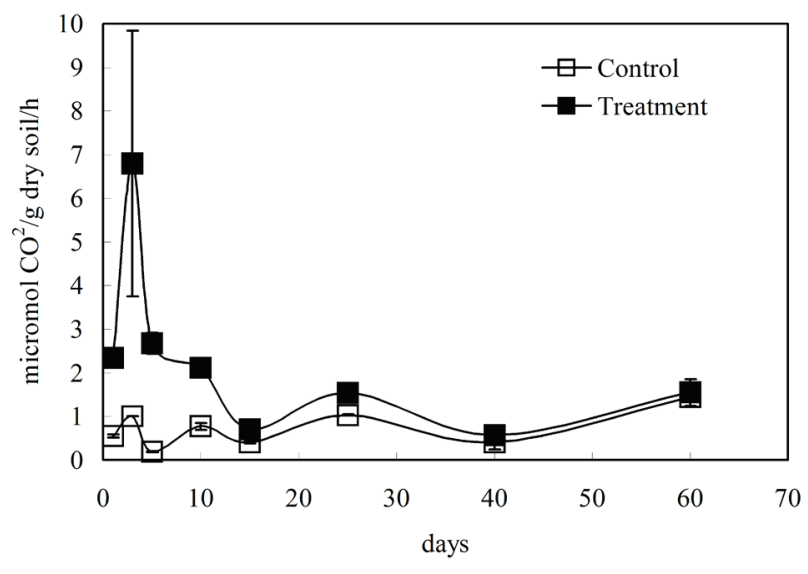

Figure 1. Basal respiration rate in either uncontaminated or gasohol- contaminated soil of a tropical forest. The soil samples were incubated at $22^{\circ} \mathrm{C}$ and kept at $60 \%$ water holding capacity. 


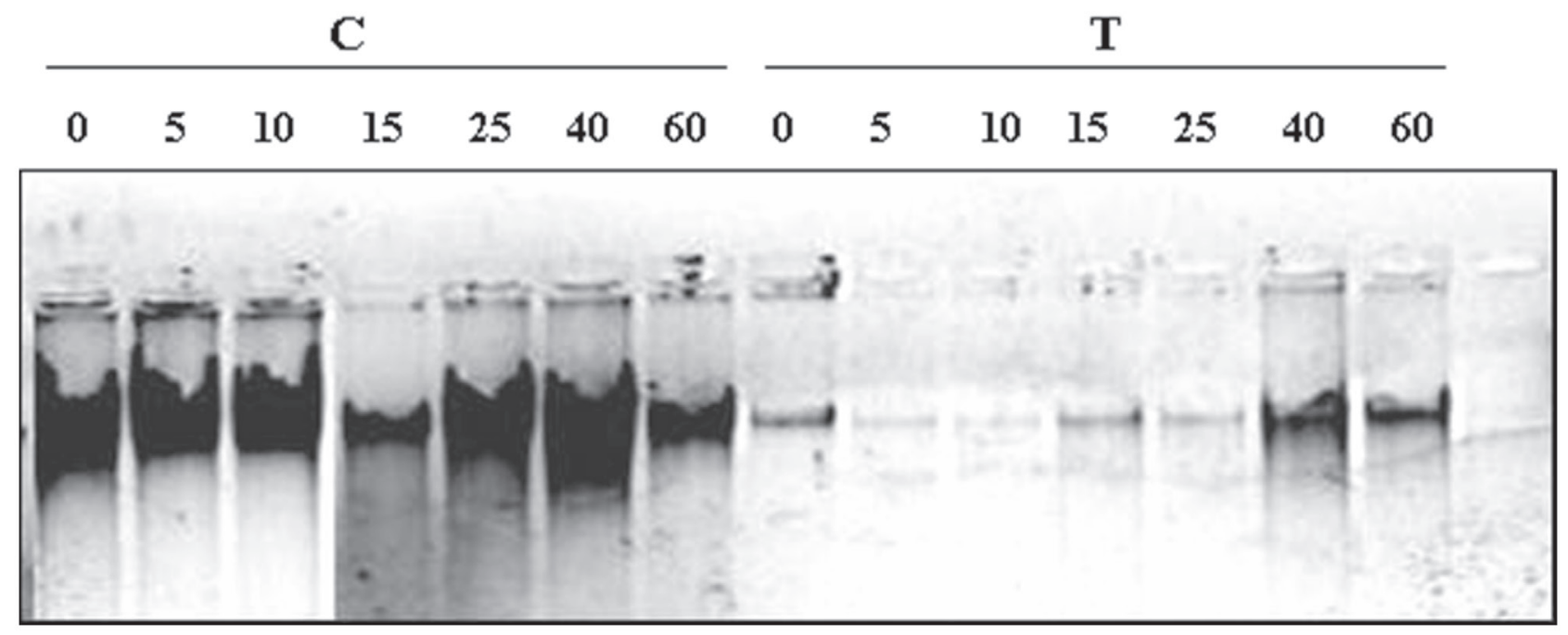

Figure 2. Agarose gel electrophoresis of total DNA extracted from the soil microbial community. Samples were taken from control soil $\left(\mathrm{C}_{0}-\mathrm{C}_{60}\right)$ and gasohol-contaminated soil $\left(\mathrm{T}_{0}-\mathrm{T}_{60}\right)$ and nucleic acids were isolated as described in material and methods.

onset of the experiment $\left(\mathrm{T}_{0}\right)$ grouped with the noncontaminated control soil $(\approx 90 \%$ similarity). The same applies to the contaminated soil at day 60 , indicating the recovery of the bacterial community structure after the biodegradation of the gasohol components (Figure 1).

\section{DISCUSSION}

The addition of gasohol caused significant and immediate increase in the respiration rate of the forest soil. The respiration rate of the contaminated soil returned to values similar to the non-
A

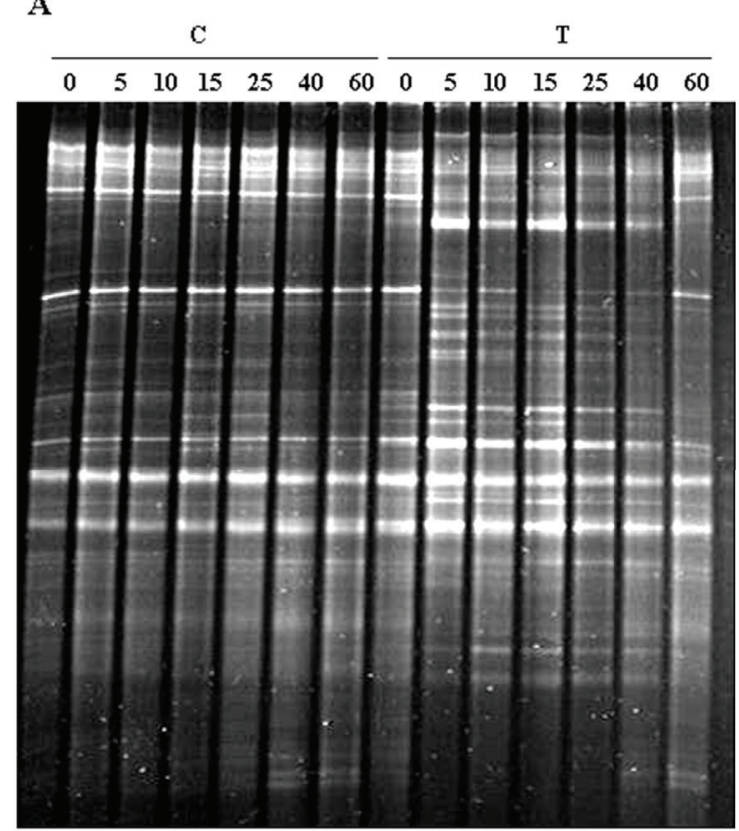

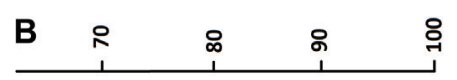

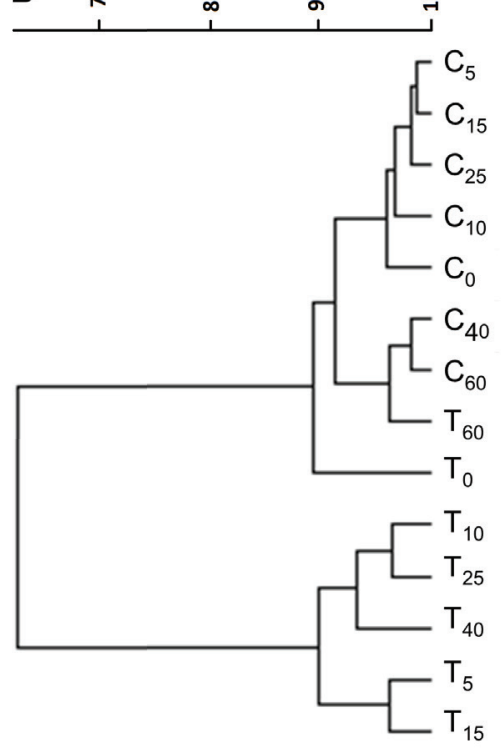

Figure 3. DGGE Analysis of PCR-amplified 16S ribosomal DNA from uncontaminated and contaminated soil DNA extracts. Gel gradient ranged from 45 to $75 \%$ denaturant (A). Soil samples were collected from 0 to 60 days after contamination from both control (C) and gasohol-contaminated (T) soil. Cluster analysis of DGGE profiles (B). Similarity dendrogram (UPGMA, Pearson correlation coefficient) of eubacterial banding patterns of control (C) or gasohol-contaminated (T) soils at differing sampling times, representing the percentage of similarity between the DGGE band profiles. The similarity dendrogram (scale $0-100$ ) was calculated from PCR-DGGE profiles shown in Fig. 3A. 
contaminated soil at 15 days after gasohol addition. This decline was attributed to the exhaustion of the newly available carbon sources resulting from the mineralization activity and partial loss of gasohol components by volatilization during air injection. The amount of total DNA recovered after 45 days from contamination is in agreement with the return of soil respiration of the contaminated treatment to basal level after 15 days, suggesting that the contaminants had been eliminated. The low yield of DNA from the contaminated soil on day zero, after only two hours of contamination (compared to the control), can be explained by the solvency potential of gasohol, and may not be an indicative of a strong and immediate effect on the microbial structure or biomass. This is reinforced by the similar DGGE profile between the contaminated and non-contaminated (control) soil.

The impact of gasohol contamination on the microbial community was shown by either significant reduction in the amount of DNA recovered from the contaminated soil and the shift in the genetic profile. The steep decrease in DNA recovery until day 10 coincided with the period of the highest shift in bacterial community profile (Figure 3A).

The biodegradation of contaminants by the microbial populations and loss of the volatile molecules during air injection paved the way to the reestablishment of the soil microbial populations. In the present case, the secondary succession that followed the contamination and contaminant removal lead to a microbial structure similar to that present in non-contaminated soil. This indicates a strong resilience of microbial the community present in soil of the Brazilian Atlantic Forest to soil contamination by gasohol.

The DGGE analysis showed the prevalence of some ribotypes in either non-contaminated control and in gasohol-contaminated soil, indicating the stability of some bacterial populations in the soil. We do not exclude the possibility that some or most of these populations were present as resting stages (e.g., endospores). However, because tropical forest soils are generally rich in a diverse organic carbon pool, the dominant bacteria tend to be generalist, and therefore able to use different $C$ sources (Laverman et al. 2005, Novak et al. 2017, Chen et al. 2019). Similar results were found by Evans et al. (2004) working with oil-contaminated soil.
The detection of new ribotypes upon contamination of soil with gasohol $\left(\mathrm{T}_{5}-\mathrm{T}_{40}\right)$ suggests the enrichment of some microbial populations that were present at low abundance in the noncontaminated soil, which were favored by the newly added carbon sources, indicating that these populations can use efficiently the components of gasohol as substrates. This in turn offers competitive advantage, resulting in the increase of the hydrocarbonoclastic populations. An additional explanation is that ecological niches previously occupied by naturally dominant populations that were inhibited (or even eliminated) by the toxic effects of the contaminants became available to these newly dominant populations (due to reduced competition). Independently of the intrinsic behavior of individual populations in response to soil contamination by gasohol, structure of the bacterial community was reestablished after only 60 days upon contamination, which is an evidence of the strong resilience of this component of tropical forest soil ecosystem.

Finally, the bacterial community of Atlantic Forest soil responds promptly to contamination by gasohol, in terms of both genetic profile and metabolic activity. Genetic profile and respiration rates returned to basal levels in just a few days, indicating a great resilience of the bacterial community in tropical Atlantic Forest soil. Future studies using other methods can reinforce the high resilience of the microbial community from Atlantic Forest soils contaminated with gasohol compounds and the key populations involved in contaminant removal.

\section{ACKNOWLEDGMENTS}

The authors are grateful to the Financiadora de Estudos e Projetos (Finep) and to the Conselho Nacional de Desenvolvimento Científico e Tecnológico (CNPq) for the financial support.

\section{REFERENCES}

Alrumman, S. A., Standing, D. B., \& Paton, G. I. 2015. Effects of hydrocarbon contamination on soil microbial community and enzyme activity. Journal of King Saud University, 27(1), 31-41. DOI: 10.1016/j.jksus.2014.10.001 
Alvarez, V. M., Marques, J. M., Korenblum, E., \& Seldin, L. 2011. Comparative bioremediation of crude oil-amended tropical soil microcosms by natural attenuation, bioaugmentation, or bioenrichment. Applied and Environmental Soil Science, 2011, 156320, 1-10. DOI: $10.1155 / 2011 / 156320$

Andrade, L. N., Araujo, S. F., Matos, A. T., Henriques, A. B., Oliveira, L. C., Souza, P. P., Chagas, P., Leão, M. M. D., \& Amorim, C. C. 2017. Performance of different oxidants in the presence of oxisol: Remediation of groundwater contaminated by gasoline/ etanol blend. Chemical Engineering Journal, 308(15), 428-437. DOI: 10.1016/j. cej.2016.09.069

Baldrian, P. 2017. Editorial: Special thematic issue on the ecology of soil microorganisms. FEMS Microbiology Ecology, 93(2), fiw237. DOI: 10.1093/femsec/fiw237

Bao, M. T., Wang, L. N., Sun, P.Y., Cao, L. X., Zou, J., \& Li, Y. M. 2012. Biodegradation of crude oil using an efficient microbial consortium in a simulated marine environment. Marine Pollution Bulletin, 64(6), 1177-1185. DOI: 10.1016/j. marpolbul.2012.03.020

Birkhofer, K., Bezemer, T. M., Bloem, J., Bonkowski, M., Christensen, S., Dubois, D., Ekelund, F, Fliebach, A., Gunst, L., Hedlund, K., Mäder, P., Mikola, J., Robin, C., Setälä, H., Tatin-Froux, F., Van der Putten,W. H., \& Scheu, S. 2008. Long-term organic farming fosters below and aboveground biota: Implications for soil quality, biological control and productivity. Soil Biology and Biochemistry, 40(9), 2297-2308. DOI: 10.1016/j. soilbio.2008.05.007

Chen, J., Xu, H., He, D., Li, Y., Luo, T., Yang, H., \& Lin, M. 2019. Historical logging alters soil fungal community composition and network in a tropical rainforest. Forest Ecology and Management, 433(15), 228-2239. DOI: 10.1016/j. foreco.2018.11.005

Corseuil, H. X., \& Marins, M. D. M. 1997. Contaminação de águas subterrâneas por derramamentos de gasolina: o problema é grave? Engenharia Sanitaria e Ambiental, 2(2), 50-54.

Demirbas,A.2009.Emissioncharacteristicsofgasohol and diesohol. Energy Sources, Part A: Recovery, Utilization, and Environmental Effects, 31(13), 1099-1104. DOI: 10.1080/10916460801907120
Duineveld, B. M., Kowalchuk, G. A., Keijzer, A., van Elsas, J. D., \& van Veen, J. A. 2001. Analysis of bacterial communities in the rhizosphere of chrysanthemum via denaturing gradient gel electrophoresis of PCR-amplified 16S rRNA as well as DNA fragments coding for 16S rRNA. Applied and Environmental Microbiology, 67(1), 172-178. DOI: 10.1128/AEM.67.1.172-178.2001

El Fantroussi, S., \& Agathos, S. N. 2005. Is bioaugmentation a feasible strategy for pollutant removal and site remediation? Current Opinion in Microbiology, 8(3), 268-275. DOI: 10.1016/j. mib.2005.04.011

Evans, F. F., Rosado, A. S., Sebastián, G. V., Casella, R., Machado, P. L. O. A., Holmström, C., Kjelleberg, S., \& van Elsas, J. D. 2004. Impact of oil contamination and biostimulation on the diversity of indigenous bacterial communities in soil microcosms. FEMS Microbiology Ecology, 49(2), 295-305. DOI: 10.1016/j. femsec.2004.04.007

Faoro, H., Alves, A. C., Souza, E. M., Rigo, L. U., Cruz, L. M., Al-Janabi, S. M., Monteiro, R. A., Baura, V. A., \& Pedrosa, F. O. 2010. Influence of soil characteristics on the diversity of bacteria in the Southern Brazilian Atlantic Forest. Applied and Environmental Microbiology, 76(14), 47444749. DOI: 10.1128/AEM.03025-09

Habe, H., \& Omori, T. 2003. Genetics of polycyclic aromatic hydrocarbon metabolism in diverse aerobic bacteria. Bioscience, Biotechnology, and Biochemistry, 67(2), 225-243. DOI: 10.1271/ bbb. 67.225

Hill, G. T., Mitkowski, N. A., Aldrick-Wolfe, L., Emele, L. R., Jurkonie, D. D., Ficke, A., MaldonadoRamirez, S., Lynch, S. T., \& Nelson, E. B. 2000. Methods for assessing the composition and diversity of soil microbial communities. Applied Soil Ecology, 15(1), 25-36. DOI: 10.1016/S09291393(00)00069-X

Jung, J., Philippot, L., \& Park, W. 2016. Metagenomic and functional analyses of the consequences of reduction of bacterial diversity on soil functions and bioremediation in diesel-contaminated microcosms. Scientific Reports, 6, 23012. DOI: 10.1038/srep23012

Khan, F. I., Husain, T., \& Hejazi, R. 2004. An overview and analysis of site remediation technologies. Journal of Environmental Management, 71(2), 95-122. DOI: 10.1016/j.jenvman.2004.02.003 
Khan, M. A. I., Biswas, B., Smith, E., Mahmud, S. A., Hasan, N. A., Khan, M. W. A. W., Naidu, R., \& Megharaj, M. 2018. Microbial diversity changes with rhizosphere and hydrocarbons in contrasting soils. Ecotoxicology and Environmental Safety, 156, 434-442. DOI: 10.1016/j.ecoenv.2018.03.006

Khan, M. A. I., Biswas, B., Smith, E., Naidu, R., \& Megharaj, M. 2018. Toxicity assessment of fresh and weathered petroleum hydrocarbons in contaminated soil- a review. Chemosphere, 212, 755-767. DOI: 10.1016/j. chemosphere.2018.08.094

Laverman, A. M., Braster, M., Röling, W. F. M., \& van Verseveld, H. W. 2005. Bacterial community structure and metabolic profiles in a forest soil exhibiting spatially variable net nitrate production. Soil Biology and Biochemistry, 37(9), 1581-1588. DOI: 10.1016/j.soilbio.2005.01.019

Leahy, J. G., \& Colwell, R. R. 1990. Microbial degradation of hydrocarbons in the environment. Microbiology Reviews, 54(3), 305-315.

Martínez-Pascual, E., Grotenhuis, T., Solanas, A. M., \& Viñas, M. 2015. Coupling chemical oxidation and biostimulation: Effects on the natural attenuation capacity and resilience of the native microbial community in alkylbenzene-polluted soil. Journal of Hazardous Materials, 300, 135143. DOI: 10.1016/j.jhazmat.2015.06.061

Mummey, D. L., Stahl, P. D., \& Buyer, J. S. 2002. Microbial biomarkers as an indicator of ecosystem recovery following surface mine reclamation. Applied Soil Ecology, 21(3), 251-259. DOI: 10.1016/S0929-1393(02)00090-2

Muyzer, G., Waal, E. C., \& Uitterlinden, A. G. 1993. Profiling of complex microbial populations by denaturing gradient gel electrophoresis analyses of polymerase chain reaction-amplified genes coding for 16s rRNA. Applied and Environmental Microbiology, 59(3), 695-700.

Novak, E., Carvalho, L. A., Santiago, E. F., \& Portilho, I. I. R. 2017. Chemical and microbiological attributes under different soil cover. Cerne 23(1), 19-30. DOI: 10.1590/01047760201723012228

Peixoto, R. S., Rosado, A. S., Coutinho, H. L., \& Rumjanek, N. G. 2002. Use of the rpoB and $16 \mathrm{~S}$ rDNA gene to analyze the bacterial diversity from native tropical soil by PCR/DGGE. Letters in Applied Microbiology, 35(4), 316-320.

Ribeiro, M. C., Metzger, J. P., Martensen, A. C., Ponzoni, F. J., \& Hirota, M. M. 2009. The Brazilian
Atlantic Forest: how much is left, and how is the remaining forest distributed? Implications for conservation. Biological Conservation, 142(6), 1141-1153. DOI: 10.1016/j.biocon.2009.02.021

Rodrigues, E. M., Kalks, K. H. M., \& Tótola, M. R. 2015. Prospect, isolation, and characterization of microorganisms for potential use in cases of oil bioremediation along the coast of Trindade Island, Brazil. Journal of Environmental Management. 156(1), 15-22. DOI: 10.1016/j. jenvman.2015.03.016

Siles, J.A., \& Margesin, R. 2018. Insights into microbial communities mediating the bioremediation of hydrocarbon-contaminated soil from an Alpine former military site, Applied Microbiology and Biotechnology, 102(10), 4409-4421. DOI: 10.1007/ s00253-018-8932-6

Tótola, M. R., \& Chaer, G. M. 2002. Microrganismos e processos microbiológicos como indicadores da qualidade dos solos. In: V. V. H. Alvarez, C. E. G. R. Schaefer, N. F. Barros, J. W. V. Mello, \& L. M. Costa (Eds.), Tópicos em ciência do solo. v. 2. pp. 195-276. Viçosa, MG: Sociedade Brasileira de Ciência do Solo.

van Elsas, J. D., Mantynen, V., \& Wolters, A. 1997. Soil DNA extraction and assessment of the fate of Mycobacterium chlorophenolicum strain PCP1 in different soils by $16 \mathrm{~S}$ ribosomal RNA gene sequence based most-probable-number PCR and immunofluorescence. Biology and Fertility of Soils, 24(2), 188-195.

Wardle, D. A., \& Giller, K. E. 1996. The quest for a contemporary ecological dimension to soil biology. Soil Biology and Biochemistry, 28(12), 1549-1554. DOI: 10.1016/S0038-0717(96)00293-3

Yu, K. S. H., Wong, A. H. Y., Yau, K. W. Y., Wong, Y. S., \& Tam, N. F. Y. 2005. Natural attenuation, biostimulation and bioaugmentation on biodegradation of polycyclic aromatic hydrocarbons (PAHs) in mangrove sediments. Marine Pollution Bulletin, 51(8-12), 1071-1077. DOI: 10.1016/j.marpolbul.2005.06.006

Submitted: 26 June 2018

Accepted: 17 March 2019 Published online: 15 May 2019 Associate Editor: Natalie Olifiers 